\title{
Guillain Barré Syndrome in a Multiple Myeloma Patient After the Autologous Transplantation: A Case Report
}

\section{Otolog Transplantasyon Sonrası Multipl Miyelom Hastasinda Guillain Barré Sendromu: Olgu Sunumu}

\author{
Ahmet SEYHANLI, Ismail SELIMOGLU ${ }^{2}$, Inci ALACACIOGLU, Fatih DEMIRKAN, Guner Hayri OZSAN ${ }^{3}$ \\ 1 Sivas Numune Hospital Hematology, SIVAS, Turkey \\ 2 Dokuz Eylul University Internal Medicine, IZMIR, Turkey \\ 3 Dokuz Eylul University Hematology, IZMIR, Turkey
}

Yazışma Adresi

Correspondence Address

\section{Ahmet SEYHANLI \\ Sivas Numune Hospital Hematology, SIVAS, Turkey \\ ahmet8563@yahoo.com}

Geliș tarihi / Received : Tem 18, 2020 Kabul tarihi / Accepted : Ağu 21, 2020 Elektronik yayın tarihi : Eyl 01, 2021 Online published

Bu makalede yapılacak atıf

Cite this article as:

Seyhanli A, Selimoglu I,

Alacacioglu I, Demırkan F, Ozsan G.H.

Guillain Barré Syndrome in a Multiple Myeloma Patient After the Autologous Transplantation: A Case Report

Akd Med J / 2021; 7(3):479-482

Ahmet SEYHANLI ORCID ID: 0000-0001-6082-2995 Ismail SELIMOGLU ORCID ID: 0000-0003-2803-3456 Inci ALACACIOGLU ORCID ID: 0000-0002-8187-7159 Fatih DEMIRKAN ORCID ID: 0000-0002-1172-8668 Guner Hayri OZSAN ORCID ID: 0000-0002-0930-6300

\begin{abstract}
Guillain-Barre syndrome (GBS) is an immune-mediated peripheral neuropathy involving multiple nerve roots and peripheral nerves. The pathogenesis remains incompletely understood, and etiology is unclear. Infections, malignancies, vaccination, and bone marrow transplantation have been accused. Plasmapheresis and intravenous immunoglobulin can be used for treatment. Multiple myeloma is a malignant disease characterized by an abnormal proliferation of clonal plasma cells. Chemotherapy and autologous transplantation are major therapies for multiple myeloma. Herein a case of multiple myeloma developing Guillain-Barre syndrome after autologous transplantation improved by plasmapheresis is presented.
\end{abstract}

\section{Key Words:}

Guillain Barre syndrome, Multiple myeloma, Peripheral autologous stem cell transplant

\section{ÖZ}

Guillain-Barre sendromu (GBS), çoklu sinir köklerini ve periferik sinirleri içeren bağışıklık aracılı bir periferik nöropatidir. Patogenez tam olarak anlaşılamamıştır ve etiyolojisi belirsizdir. Enfeksiyonlar, maligniteler, aşılama ve kemik iliği nakli suçlanmıştır. Plazmaferez ve intravenöz immünoglobulin tedavi için kullanılabilir. Multipl miyelom, klonal plazma hücrelerinin anormal proliferasyonu ile karakterize malign bir hastalıktır. Kemoterapi ve otolog transplantasyon, multipl miyelom için birincil tedavilerdir. Burada plazmaferez ile düzelen otolog transplantasyon sonrası Guillain-Barre sendromu gelişen multipl miyelom olgusu sunulmuştur.

\section{Anahtar Sözcükler:}

Guillan Barre sendromu, Multiple myeloma, Periferik otolog kök hücre nakli

\section{INTRODUCTION}

Multiple myeloma (MM) is a hematological malignant disease characterized by an abnormal proliferation of clonal plasma cells. The most common symptoms are bone pain, anemia, hypercalcemia, and renal failure $(1,2)$. The mean life expectancy of myeloma is $3-5$ years. But this period may be prolonged by autologous stem cell transplantation (ASCT) and novel agents. ASCT remains the standard of care for newly diagnosed multiple myeloma in young and selected fit elderly patients (3). There are variable complications described after ASCT, such as infections, mucositis, cytopenias, etc. (4). Neurological problems and infections are often an important cause of morbidity and mortality (5). Guillain-Barre syndrome (GBS) is the most common 
cause of acute generalized paralysis (6). It is a demyelinating polyradiculopathy characterized by albuminocytological dissociation in CSF fluid, usually presenting with acute onset of areflexia and muscle weakness rising from the lower extremities to upwards but, the pathogenesis remains incompletely understood and its etiology is unclear $(7,8)$. Infections, malignancies, vaccination, and bone marrow transplantation have been accused of the etiology $(6,9,10)$. The incidence of Guillain-Barré syndrome is thought to be 0.25 to 0.65 per 1000 and 0.6 to 2.2 per $1000 \mathrm{C}$ jejuni infection and primary cytomegalovirus infection, respectively (11). Other infective agents with a strong association of GBS are Epstein-Barr virus, varicella-zoster virus, and Mycoplasma pneumonia (12-14). Intravenous immunoglobulin (IVIG) therapy or plasmapheresis is effective for the treatment. Herein, we report a case of GBS associated with ASCT.

\section{CASE REPORT}

A 62 -year-old woman was diagnosed with IgG kappa, International Staging System Stage I Multiple myeloma. She was initially treated with four cycles of Bortezomib, cyclophosphamide, and dexamethasone. Ten months after the diagnosis, she received ASCT following high dose melphalan $200 \mathrm{mg} / \mathrm{m} 2$. She was discharged at +23 th day of transplantation with well being. At +36 th

days of ASCT, she complains about waist and back pain that persisted day and night, not decreased with movement, not responded to paracetamol, but partially relieved with codeine. In one week of described these symptoms, the pain severity increased and has stopped responding to codeine. She developed gradual onset of ascending weakness and numbness starting from his feet and progressed to the thigh and upper limbs over a week. Also, hoarseness was added 5 days before hospitalization. However, before these complaints, there was no complaint of upper respiratory tract infection findings, cough, sputum, fever, and diarrhea. At the time of transferring to our department, she could not stand and was having trouble wearing her clothes. Physical examination revealed decreased sensation to a light touch on extremities (especially lower extremities) and decreased muscle strength as grade $1 / 5,3 / 5$, and $4 / 5$ of distal and proximal muscles of lower extremities and both proximal and distal muscles of upper extremities, respectively. The ankle jerk reflexes and knee jerk reflexes have disappeared bilaterally with no Babinski sign. Cranial nerve examination revealed left facial paralysis with no additional pathological findings. No bulbar symptoms, fasciculations, cramps, autonomic symptoms, muscle atrophy or respiratory problems were noted, and no headaches or preceding history of infection or illness were present. The patient's vital signs were stable. Although new symptoms were present, it was notable that the patient experienced a partial remission, with a decrease in the serum $\mathrm{M}$ protein, $\mathrm{K} / \mathrm{L}$ ratio was 2.0 ( before the ASCT ratio was 2.7). The sedimentation rate was unremarkable. Routine blood examinations like coagulation tests, hepatic tests, ionogramme, TSH were also unremarkable except anemia $(10.8 \mathrm{~g} / \mathrm{dl})$. No signs of the inflammatory process were detected. Serum folate, vitamin B12, and calcium levels were within normal limits. HbA1C was 4.9, and there were not any signs of diabetes mellitus. Blood and urine culture were negative. Microbiological and viral investigations were of no use, only demonstrating former contacts with cytomegalovirus, Epstein-Barr virus, rubella virus, and toxoplasma. Other viruses and bacterial serologic tests were negative (Herpes virus type I and II, varicella, HIV, hepatitis (A, B, C) virus, syphilis ).

Multiple PCR tests were performed for respiratory viruses (influenza, parainfluenza, RSV, metapneumovirus, coronavirus, rhino/enterovirus, adenovirus, bocavirus, M.pneumoniae) and were negative. Also, there were not any growth in stool culture. Brain scans using computed tomography and gadolinium-assisted magnetic resonance imaging showed chronic ischemic and atrophic changes in the left frontal lobe and lacunar infarction area, but this was insufficient to explain the patient's symptoms. Vertebral MRI revealed discal pathologies in the cervical and lumbar region that did not cause neural compression. In the thorax and abdomen CT, there was only a cyst in the liver. Cerebrospinal fluid (CSF) showed albumino-cytologic dissociation, with increased protein level (298mg/dl n:15-40mg/dl), low glucose $(55 \mathrm{mg} / \mathrm{dl})$ and low cellularity. Cytopathology was normal (especially no lymphoma cells), as well as bacterial cultures. ARB was negative for M.tuberculosis. The patient's EMG result was found to be compatible with demyelinating polyneuropathy in which the sural nerve was preserved. GBS was diagnosed, and then plasma exchange was performed immediately.

After a total of 8 sessions of plasma exchange, the patient became able to ambulate on her own. Neither respiratory nor neurological complications developed during the following period.

\section{DISGUSSION}

Some neurological complications can develop after bone marrow and other organ transplantation. In the literatüre, these neurological complications were reported in the $50 \%-70 \%$ of patients mostly including the central nervous system and less frequently the peripheral nervous system (15-17). GBS, that one of these complications, is a complex autoimmune disease with many unanswered questions at both the clinical and laboratory levels. The pathogenesis of GBS may be explained by an abnormal immune response to an antecedent event, most commonly an infection. While approximately two-thirds of patients report a respiratory or gastrointestinal infection in the weeks before the onset of symptoms (18). in the present patient, no clinical symptoms or signs were present to suggest an antecedent infection, and the laboratory tests, including a full blood count, serologies, urinalysis, and cultures, were normal. Furthermore, several other common causes for autonomic neuropathy, in particular metabolic (diabetes and hypovitaminosis), inflammatory (autoantibodies) or toxic (alcohol), were ruled out by investigation. In the literature, multiple myeloma patient developing GBS after the first dosage of bortezomib therapy was reported. Authors thought bortezomib in the etiology after exclud- 
ing all possible causes. This was a diagnosis of exclusion (9). In our patient, there was also bortezomib usage but it was 4 months since the last dose. She had a history of 7 days oseltamivir use only 10 days before BMT otherwise she did not have any complaints at all, except for a nonspecific symptom such as fatigue. Treatment was given prophylactically because it was a period after PBSCT.

Besides, recurrence of polyneuropathy may occur, in patients undergoing PBSCT for multiple myeloma, due to the infiltration of nerves by plasma cells (19). Direct plasma cell infiltration of the nerves was unlikely in the present patient, as there were no signs or symptoms of nerve infiltration and active disease. The patient's response to PBSCT was determined as a partial response by immunofixation electrophoresis. Excluding the other causes of GBS, the patient was diagnosed with GBS secondary to PBSCT. Using neurophysiologic testing Openshaw et al. reported 10 cases $(0.7 \%)$ of demyelinating polyneuropathy among 1370 transplants performed from 2/83 to $3 / 93$, but GBS is rarely associated with BMT (20). Among 793 allogeneic and 650 autologous BMT performed from $1 / 1982$ to $4 / 1996$, Wen et al. reported that only 4 patients $(0.3 \%)$ developed GBS after allogeneic transplants and none after autologous transplants (21). It has been also speculated that high dose chemotherapy in PBSCT may directly induce neural sheath damage-causing exposure of the neural antigens to immune reactive cells activated by antecedent infection (15). In our case, we report GBS detected after autologous BMT in a patient with multiple myeloma excluding all any other probable causes of GBS and as we know the previous series there was no case reported before. In the literature, there are a reported total of 11 patients who developed GBS after autologous BMT. Those cases associated with BMT tended to be younger with the median age of 36 ( range 7-62) and the median onset time of all cases is 18 weeks (range 2 days-3 years). They were transplanted due to acute myeloid leukemia, acute lymphoblastic leukemia, Hodgkin and Non-Hodgkin lymphoma, chronic myeloid leukemia, breast cancer, and multiple myeloma (1 patient). As far as we know, our case was the second to develop GBS among patients undergoing autologous bone marrow transplantation due to multiple myeloma, and no other agent in etiology was detected. She also improved with plasmapheresis therapy.

\section{GONGLUSION}

GBS is an infrequent complication associated with transplantation. It is a heterogeneous condition mediated by various pathogenetic mechanisms. Regardless of the mechanism, plasmapheresis and IVIg are the primary therapy for GBS and therapy should begin immediately.

Finansman ve Mali destek: Yoktur Çıkar Çatışması : Yoktur 


\section{REFERANCE}

1. Kyle R, Rajkumar SV: Criteria for diagnosis, staging, risk stratification and response assessment of multiple myeloma. Leukemia 2009; 23(1):3-9.

2. Morgan G, Davies F: Evolving treatment strategies for myeloma. British journal of cancer 2005; 92(2):217-221.

3. Al Hamed R, Bazarbachi AH, Malard F, Harousseau J-L, Mohty M: Current status of autologous stem cell transplantation for multiple myeloma. Blood cancer journal 2019; 9(4):1-10.

4. Graff TM, Singavi AK, Schmidt W, Eastwood D, Drobyski WR, Horowitz M, Palmer J, Pasquini M, Rizzo DJ, Saber W: Safety of outpatient autologous hematopoietic cell transplantation for multiple myeloma and lymphoma. Bone marrow transplanta tion 2015; 50(7):947-953.

5. Ruzhansky KM, Brannagan III TH: Neuromuscular complications of hematopoietic stem cell transplan tation. Muscle \& nerve 2015; 52(4):480-487.

6. Castro LH, Ropper AH: Human immune globulin infusion in Guillain-Barré syndrome: Worsening during and after treatment. Neurology 1993; 43(5):1034.

7. Durrheim DN: Guillain-Barré Syndrome. Hospital (Burkina Faso) 2004; 160:559-562.

8. Fujisaki G, Kami M, Murashige N, Kishi Y, Hori A, Chizuka A, Ugawa Y, Kobayashi K, Tanosaki R: Guillain-Barré syndrome associated with rapid immune reconstitution following allogeneic hemato poietic stem cell transplantation. Bone marrow trans plantation 2006; 37(6):617-619.

9. Khouri J, Majhail NS: Advances in delivery of ambulatory autologous stem cell transplantation for multiple myeloma. Current opinion in supportive and palliative care $2017 ; 11(4): 361-365$.

10. Xu Y-L, Zhao W-H, Tang Z-Y, Li Z-Q, Long Y, Cheng P, Luo J: Guillain-Barre syndrome in a patient with multiple myeloma after bortezomib therapy: A case report. World Journal of Clinical Cases 2019; 7(18):2905.

11. Hadden R, Karch H, Hartung H-P, Zielasek J, Weiss brich B, Schubert J, Weishaupt A, Cornblath D, Swan A, Hughes R: Preceding infections, immune actors, and outcome in Guillain-Barré syndrome. Neurology 2001; 56(6):758-765.

12. Jacobs B, Rothbarth P, Van der Meché F, Herbrink P, Schmitz P, De Klerk M, Van Doorn P: The spectrum of antecedent infections in Guillain-Barré syndrome: a case-control study. Neurology 1998;51(4):1110-1115.

13. Orlikowski D, Porcher R, Sivadon-Tardy V, Quin campoix J-C, Raphaël J-C, Durand M-C, Sharshar T, Roussi J, Caudie C, Annane D: Guillain-Barré syndrome following primary cytomegalovirus infec tion: a prospective cohort study. Clinical infectious diseases 2011; 52(7):837-844.

14. Kang J-H, Sheu J-J, Lin H-C: Increased risk of Guillain-Barré Syndrome following recent herpes zoster: a population-based study across Taiwan. Clinical infectious diseases 2010; 51(5):525-530.

15. Zhang L, Arrington S, Keung Y-K: Guillain-Barré syndrome after transplantation. Leukemia \& lymphoma 2008; 49(2):291-297.

16. Patchell RA: Neurological complications of organ transplantation. Annals of Neurology: Official Journal of the American Neurological Association and the Child Neurology Society

1994; 36(5):688-703.

17. Patchell RA, White CL, Clark AW, Beschorner WE, Santos GW: Neurologic complications of bone marrow transplantation. Neurology

1985; 35(3):300.

18. Poropatich KO, Walker CLF, Black RE: Quantifying the association between Campylobacter infection and Guillain-Barré syndrome: a systematic review. Journal of health, population, and nutrition 2010; 28(6):545.

19. Richardson PG, Laubach JP, Schlossman RL, Mitsia des C, Anderson K: Complications of multiple myeloma therapy, part 1: risk reduction and manage ment of peripheral neuropathy and asthenia. Journal of the National Comprehensive Cancer Network 2010; 8(Suppl_1):S-4-S-12.

20. Openshaw H, Slatkin N: Openshaw H, Slatkin N. CLINICAL SPECTRUM CT DEMYELINATING POLYNEUROPATHY AFTER BONE-MARROW TRANSPLANTATION (BMT). Paper presented at: Neurology1994.

21. Wen P, Alyea E, Simon D, Herbst R, Soiffer R, Antin $\mathrm{J}$ : Guillain-Barre syndrome following allogeneic bone marrow transplantation. Neurology 1997; 49(6):1711-1714. 